\title{
3D print additive technology as a form of textile material substitute in clothing design - interdisciplinary approach in designing corsets and fashion accessories
}

\author{
DOI: $10.35530 / I T .069 .03 .1430$
}

JASMINKA KONČIĆ

JOSIPA ŠČAPEC

\section{REZUMAT - ABSTRACT}

Tehnologia aditivă de imprimare 3D ca formă de substitut al materialului textil în proiectarea îmbrăcămintei abordare interdisciplinară în proiectarea corsetelor și a accesoriilor de modă

Acest studiu de cercetare investighează aplicarea tehnologiei aditive de imprimare 3D în designul vestimentar. Studiul are ca scop găsirea opțiunilor de proiectare pentru articolele de îmbrăcăminte prin înlocuirea materialului textil cu soluții tehnologice noi. Lucrarea se concentrează pe cercetarea interdisciplinară a modelelor inovatoare de corsete și accesorii de modă, realizate prin utilizarea tehnologiilor aditive de imprimare 3D. Principalul obiectiv al lucrării este procesul interdisciplinar de creare a articolelor de îmbrăcăminte, variind de la schițe preliminare la prototipuri în trei domenii diferite: arta contemporană, design vestimentar și tehnologia aditivă.

Cuvinte-cheie: corset, tehnologia aditivă, imprimare $3 D$, sculptura mobile

3D print additive technology as a form of textile material substitute in clothing design - interdisciplinary approach in designing corsets and fashion accessories

This research paper enquires into the application of $3 D$ print additive technology in fashion design. The research aims to find the design options for garments by substituting the textile material with new technological solutions. The focus of the paper is the interdisciplinary research of innovative corset and fashion accessories designs made using $3 D$ print additive technologies. The main focus of the work is the interdisciplinary process of creating clothes ranging from preliminary sketches to prototypes within three different areas: contemporary art, fashion design and additive technology.

Keywords: corset, additive technology, 3D print, mobile sculpture

\section{INTRODUCTION}

Historically, clothes manufacturing and design are linked to the use of textile materials which are still commonly used in the production of clothing today. Any attempt to resort to another type of material fundamentally was governed by meeting specific functions dictated by the purpose of clothing, not dictated by the official fashion. While alternative materials in the history of clothing were intended for making specific purpose clothes (e.g. metal, wood and leather in making of military clothing), the contemporary fashion sees in them the primary functional character, but also recognizes the aesthetic and conceptual potential and uses them confidently in the creation of fashion collections (Iris van Herpen Lucid 2016, Alexander McQueen Coiled Corset 1999, Hussein Chalayan Bodice 1995, Issey Miyake Rattan Suit $1982 \ldots)$ [1-3]. It is interesting that in most of the above examples it is about the shaping of corsets or garments inspired by corsets. The reason for this can be found in the manner of treating the textile material used for making traditional corsets in which the textile materials are further reinforced with metal or wire structures thus eliminating the textile softness and transforming it into a new material with altered properties. The modern era offers new technological possibilities to completely replace the textile material in the making of clothes. The growing interest of fashion designers for the production of fashion collections using the 3D additive technology is not surprising. This technology is now widely used and its application in fashion is rapidly growing [4]. Although the manufacturing using additive technology production is most commonly found in the aerospace and automotive industries and medicine, innovations in the application of new polymer and metal materials can be encountered in other areas. Because of the specificity, fashion design and accompanying fashion industry should be singled out because the additive technology is used for the production of fashion accessories and complete garments. The postmodern time opens up the possibility of a new interdisciplinary aesthetics whose task is to connect technology, art and design. The transformation of the body into a living machine - body cyborgization - takes place simultaneously with the transformation of technology into a new body/outfit. Cognitive body cybernetics therefore leads to connecting life, body, technology, art and design. As one of the most illustrative examples of the use of a 3D print additive techniques in fashion design the designer is Iris van Herpen [5] who stands out with her highly sculptural clothing 
products. As a fashion designer she offers an important clothing design example; due to the skeletal structure it is a conceptual and aesthetic connection to the Relief collection by the fashion designer Josipa Ščapec. A corset, created in the Relief collection and its fundamental hallmark, is based on the idea of the thin waist affirmation by Victorian corsets of the 19th century which resulted in an extremely rigid garment. This 3D print additive technology has been recognized as a good opportunity for the negation of the fundamental values of immobility and rigidness in Victorian corsets. With the inversion of the values, it was attempted to translate rigidness into mobility without losing the ultimate aim - to emphasize the narrow waist. The aim was to achieve a corset that moves with the body, quite the opposite to the rigid historical template.

\section{EXPERIMENTAL PART}

First phase of research: corset - rigidness vs. pliability

In the first phase of work on the Relief collection a research was done on the historical context of the corset development. For a more detailed research, it was necessary to look at a historical overview of the corset development and design from an etymological, structural and aesthetic perspective. A corset (German Korsett, French corset $\approx \operatorname{cor}(p) s$; body) already in its definition emphasizes the body in three situations: aesthetic, medical and protective [6]. In the aesthetic context it is perceived as a part of women's underwear that shapes the waist; in the medical context it represents the armour of skin or plaster to be placed around the torso usually due to deformations or fractures of the spine and a bulletproof vest in the protective context. From the three interpretations of a corset its basic characteristic clearly forms: a corset defined as a rigid copy of the waist. In the formative sense it is achieved by a direct framing of its pattern shapes in order to reduce the clothing silhouette. In this context it seemed interesting for this research to attempt to redefine the meaning: the idea of inversing the meaning as a guideline of which there are examples and recognition in the history of clothing. It is interesting that the first interpretation of the corset was defined by pleating, rather than tailoring the waist (Snake goddess statue from $1650 \mathrm{BC}$ and Renaissance corsets of the 16th century). Until the Victorian corset in the 19th century, corsets did not emphasize the curves as later models did, but shaped the body in a fashionable cylindrical shape [7]. They had straps and ended at the waist smoothing and lifting the breast area. In the beginning they were made of steel, but later were softened using fish bone and cloth, such as twill, satin and silk. In the design of modern corsets there are examples created through the processes of deconstruction, replacing its meaning (a corset becomes the sweater
Comme des Garcons) and introducing alternative materials which are favoured by Japanese designers Rei Kawakubo, Issey Miyake and Junko Koshino. These works are a good example of an art and fashion interrelation emphasizing the interdisciplinary approach to the design. In further research the characteristics of a corset will be associated with the work aesthetics and philosophy of a Croatian artist Miroslav Šutej. With his mobile graphics and sculptures he is an excellent interdisciplinary link in creating models of a corset and bracelets, also he himself gave considerable thought to fashion and clothing.

Second phase of research: Miroslav Šutejaesthetics and design of mobile sculpture

After exploring the historical context of the corset development comes the second phase of research, which carefully considers the aesthetic and structural value of the garment. The principles on which the appearance of a corset and the fashion accessories bracelets tend to be created are present in the renowned works of art by a Croatian artist Miroslav Šutej (1936-2005). He is one of the most important representative of the art movement Nove tendencije. Works by Miroslav Šutej are characterized by the purity of concept, the imagination of composition and the high technical quality of performance. Forming his artistic expression within the optical art, in his works there is a strong tendency for converting optical into tactile and that is apparent across the entire Šutej's work starting from drawings to sculptures and site-specific works. The work Bum-Bum I-68 (1968) is taken as a template for further research. It is a mobile sculpture - an object of expressive colours based on the complementary contrast of red and green, which is used to clearly evoke the effect of movement and explosion based on the fundamental stylistic features of optical art [8].

The work consists of disconnected wooden skeleton on whose limbs small balls are placed. The impression of explosive radial movement is compositionally organized from the centre of the sculpture itself. It is of great importance for the research that the sculpture is made of beads which are actually bearings to accommodate the resilient limbs and to upgrade a whole range of smaller bead elements. A similar approach will be used in the construction of a corset and bracelets. The sculpture and the observer are in a dynamic interactive relationship where the observer also participates in shaping the appearance of the sculpture. As the corset and bracelet from the Relief collection follow the individual characteristics of the body that wears them.

\section{Third stage of research: ad technology - originality vs. Ready-made}

In order to possibly start with the creation of the models for the Relief collection it was important to investigate what modern technologies and media were 
available for designing the collection. Due to the complexity of the concept, the mobile mesh structure of a corset and the related accessories, plus excluding the use of textile materials, the decision was to use the additive technologies and the processes of 3D printing for the prototype as the perfect medium for individual production. One of the reasons for selecting the 3D print additive technology is that the meeting point of the additive technology and the fashion design is not one of a producer and a fashion designer but more of a consumer and the consumer's needs to personalize the appearance. It is the additive manufacturing that offers the ability to create a personalized unique item of clothing, which in the fashion world is of crucial importance when creating a consumer's personal/fashion identity. The new 3D print additive technology will be used for the purpose of changing the historical fundamental characteristics in a Victorian corset, which is changing an extremely rigid and static garment into a garment which is pliable and mobile and which provides the body with comfort.

The modern 3D print additive processes have been developing and used more frequently since the middle 1980s. They have gone through several stages of development during their use: RP (Rapid Prototyping), RT (Rapid Tooling) and RM (Rapid Manufacturing) [9]. Their main characteristic of a unique and smallscale production has been recognized as a great advantage and as a possibility of leaving the trend of mass production. The uniqueness of a product derived by the $3 \mathrm{D}$ print additive technology is guaranteed by the manner of production. The method of making a desired product is carried out by adding materials layer by layer until the final product is made. The technique is named printing because of its similarity to ink jet printing. The difference is that in the 3D printing instead of the ink either adhesive or glue is used.
Fourth stage of research: production and work on prototype

The work on the production of prototypes for the Relief collection is divided into several stages. These include creative research, technical preparation and the production of the prototype. The creative research includes brainstorming and making of the initial sketches on a specified concept as a direct association to the study of the historical context of the corset development. The study of the historical concept of a corset adds to it additional concept of liberation and emancipation of women's bodies, which becomes obvious when focusing on breathing. The concept of mobility is introduced, which brings us to the aesthetic qualities of a mobile sculpture by Miroslav Šutej and ultimately to the deconstruction of a corset in the physical and sociological sense. By the inversion of the organic (body, torso) and technical elements (corset construction) a complete freedom of movement and breathing is achieved, which makes it extremely functional.

\section{CONSTRUCTION PROCESS OF MECHANICAL MOVING JOINT IN COMPUTER PROGRAMMES PTC CREO PARAMETRIC}

Elaboration of the Relief collection model started by hand-sketched drawing (figure 1). The sketches roughly determined the silhouette of a model corset, the bracelet and necklace position in relation to the body as well as the desired aesthetic properties. Moving away from the static and the desire for the mobility of corset and fashion accessories as well as the abandonment of textile materials have resulted in the introduction of moving joints and their mutual interaction. The model corset in the collection is deprived of the classic construction as one of the main distinguishing characteristics in the corset design and it is replaced with the mechanism of moving joints which

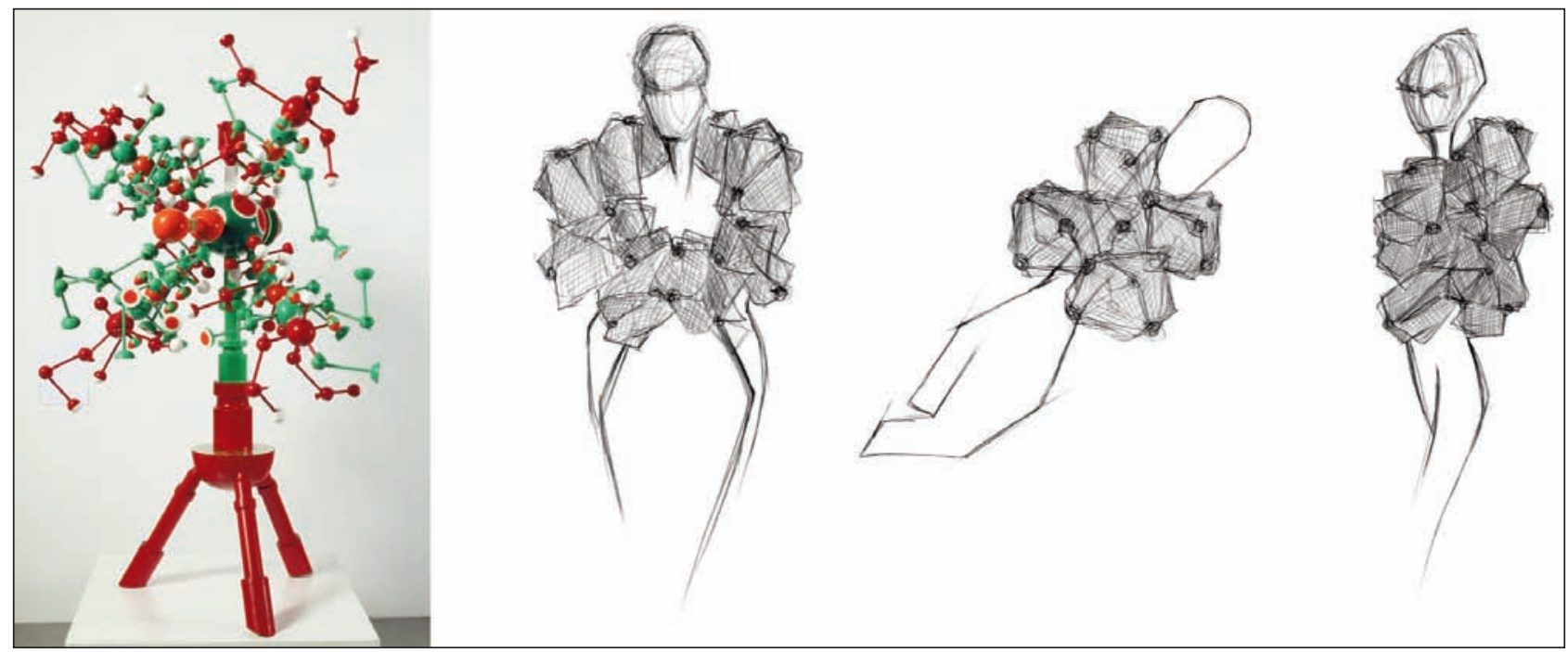

Fig. 1. Miroslav Šutej, Bum-bum I-68, 1968, mobile sculpture (left); Josipa Ščapec, drawings for the Relief collection following the aesthetics of the work by Miroslav Šutej, Bum-bum I-68 (1968) (right) 


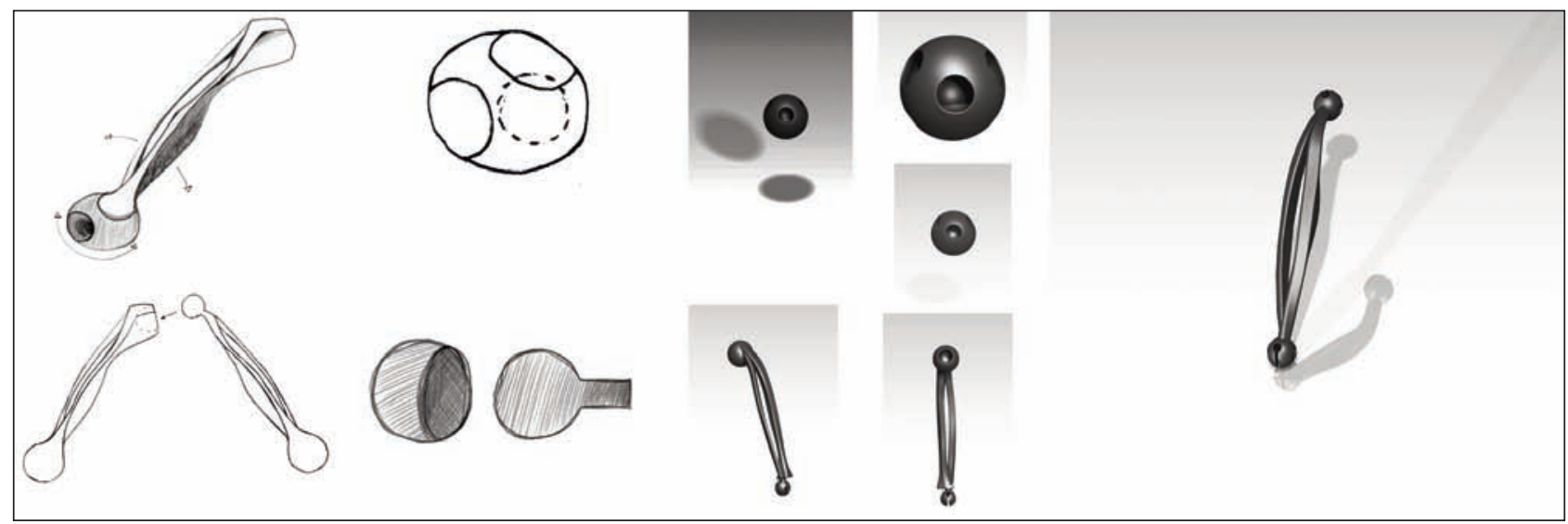

Fig. 2. Elaboration of moving joints and bearings from preliminary sketches to computer construction

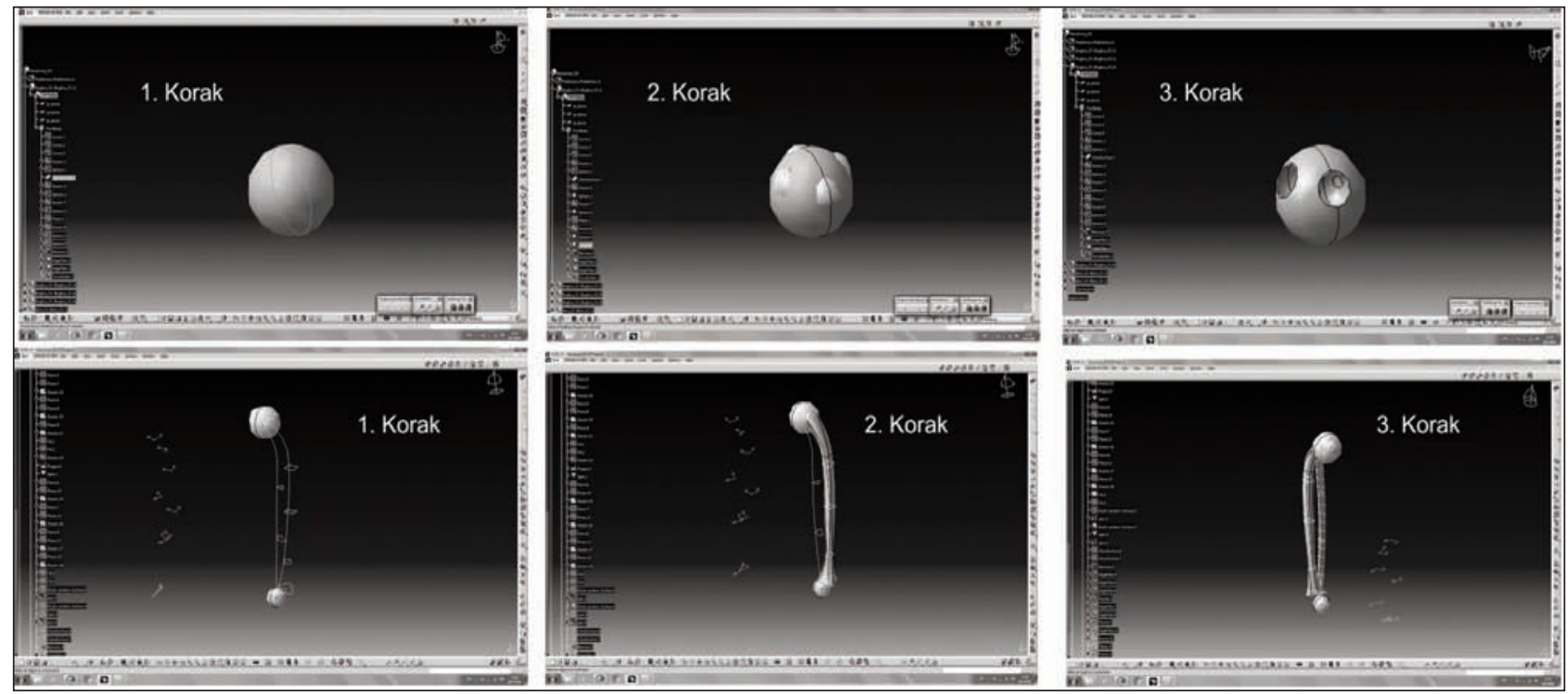

Fig. 3. Steps in moving joints construction (above) and mobile limbs (below)

is the foundation for the entire structure in the Relief collection. The moving joint and limbs were inspired by the bones and joints of the human body which suffered under a Victorian corset (figure 2). The bones of the torso that were trapped underneath a corset now appear as a metaphor in the form of mechanical clothes and accessories worn on the body. The body forms the shape of a model and not vice versa as it was the case when wearing a Victorian corset in the 19 th century.

The construction process of the moving joints mechanism was carried out in three steps: defining the sphere and cuboid as the foundation for the design, determining their size and designing the shapes most similar to the initial sketches. Figure 3 shows the steps of construction of the moving bearing. The bearing is holed out in three or four places depending on the position of the body part on which it rests. By determining the biggest prominence and indentation on the human body, the positions of bearings were established. These were six key points, three on the front (shoulder, upper chest, waistline) and three on the back (blades, the seventh cervical vertebra and waistline). Because of the proportion of a female torso, the positions such as breast demanded four holes on a bearing, while in the area of the waistline, which is convex, three holes were necessary. In the area of the shoulder blades and sleeves two holes were sufficient. The holes are spaces for the placement of the limbs and shaped to follow their forms and dimensions. The design of the limbs begins by defining the dimensions of sphere and cuboid surfaces that in their final stylized form resemble human bones. The shape of the limbs changes depending on their placement on the body: chest and hips take on slightly curved arc to the body while in the waist they take a bow-like shape facing the opposite direction i.e. the space.

\section{CONSTRUCTION PROCESS OF CORSET AND FASHION ACCESSORIES (NECKLACE AND BRACELET) IN COMPUTER PROGRAMME PTC CREO PARAMETRIC}

The construction of the model corset and fashion accessories is based on individually connecting mechanical moving parts using the "click" method. 


\begin{tabular}{|l|l|l|l|}
\hline & CORSET & BRACELET & NECKLACE \\
\hline Number of bearings & 168 & 32 & 26 \\
\hline Number of limbs & 198 & 40 & 24 \\
\hline Length of front limbs & $\begin{array}{l}5 \mathrm{~cm} \text { (chest) } \\
6 \mathrm{~cm} \text { (waistline) } \\
7 \mathrm{~cm} \text { (shoulders) }\end{array}$ & $5 \mathrm{~cm}$ & $\begin{array}{l}6 \mathrm{~cm} \text { (shoulders, area } \\
\text { below neck) }\end{array}$ \\
\hline Length of back limbs & $\begin{array}{l}6 \mathrm{~cm} \text { (waistline, shoulder blades) } \\
8 \mathrm{~cm} \text { (shoulders, seventh cervical } \\
\text { vertebra) }\end{array}$ & $5 \mathrm{~cm}$ & $\begin{array}{l}10 \mathrm{~cm} \text { (seventh cervical } \\
\text { vertebra, shoulders) }\end{array}$ \\
\hline Bearing diameter on body & $1.4 \mathrm{~cm}$ & $1.4 \mathrm{~cm}$ & $1.4 \mathrm{~cm}$ \\
\hline Bearing diameter in space & $0.7 \mathrm{~cm}$ & $0.7 \mathrm{~cm}$ & $0.7 \mathrm{~cm}$ \\
\hline Hole profile on bearings & $0.4 \mathrm{~cm}$ & $0.4 \mathrm{~cm}$ & $0.4 \mathrm{~cm}$ \\
\hline
\end{tabular}

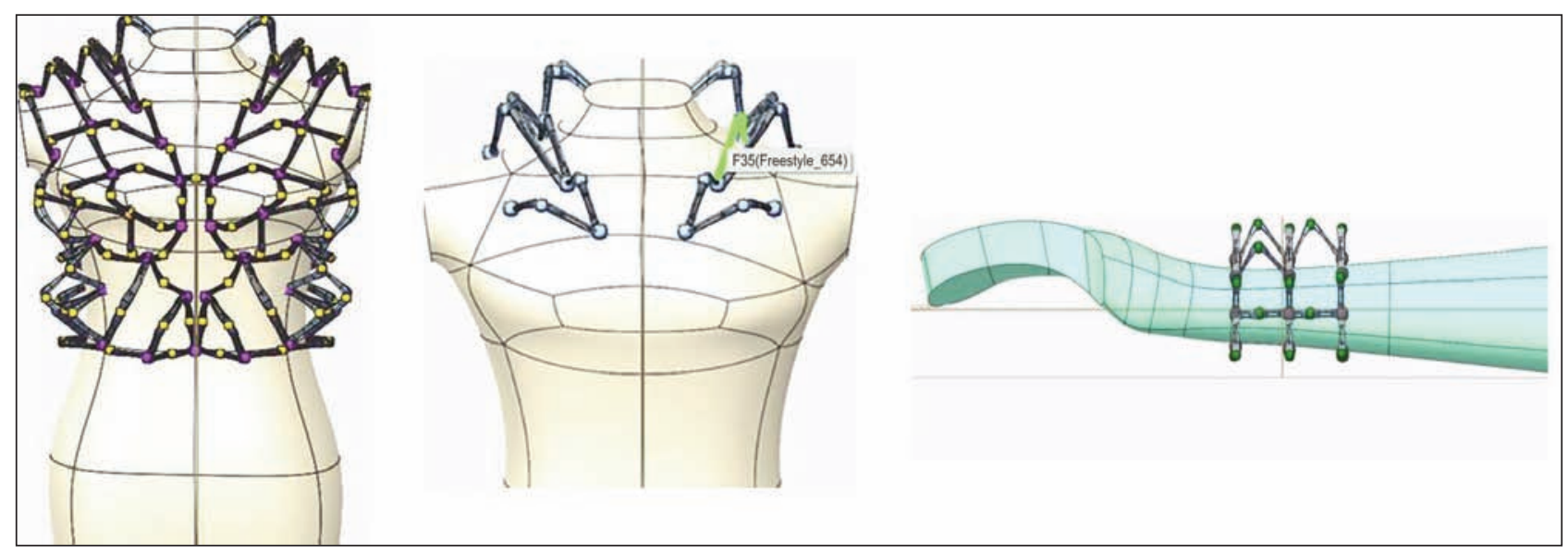

Fig. 4. Construction of corset and fashion accessories in the program PTC Creo Parametric 23

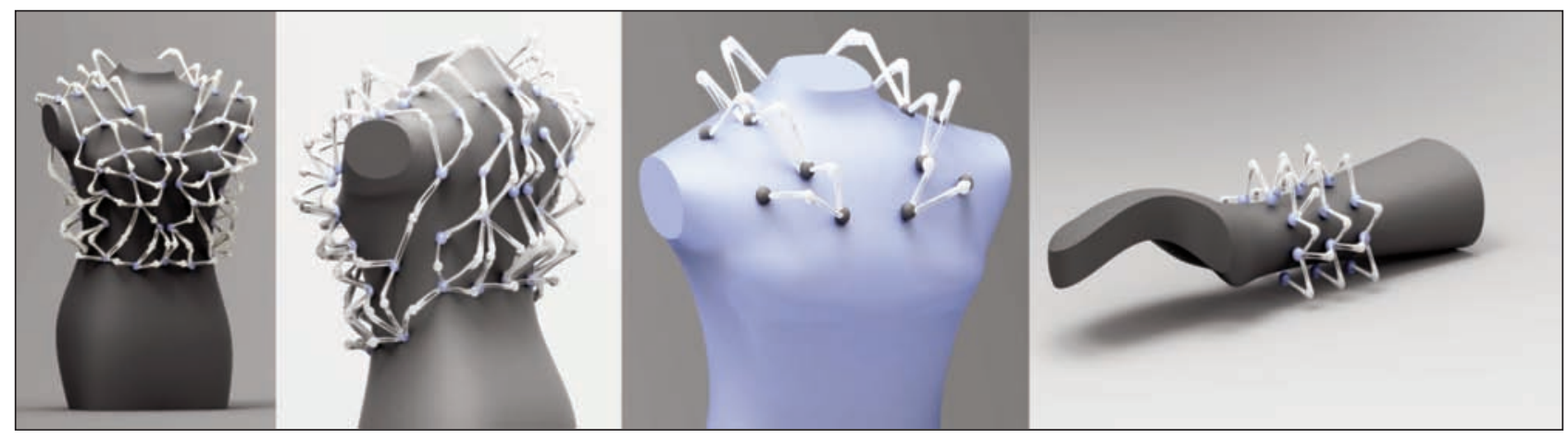

Fig. 5. Rendering of 3D models

This is made possible by a small longitudinal incision of $0.1 \mathrm{~cm}$ on limbs balls. To avoid material tear there is a cavity in bearings of the same size as the additional part on the limbs that fits the cavity which is $0.4 \mathrm{~cm}$ in size. The models are constructed in a computer program PTC Creo Parametric 23 (figures 4 and 5). Due to different proportions of the human body parts, the mechanical moving parts are designed in sizes from 5 to 10 centimeters (table 1 ) where the limbs cannot be less than $5 \mathrm{~cm}$. The universal clothing sizes ranging from $X X S$ to $X X X L$ are ensured by this. For this reason the corset and fash- ion accessories completely follow the silhouette of the body and adhere to the torso.

\section{RESULTS AND DISCUSSIONS}

The prototype bracelet from Relief collection is printed on the Stratasys machine Connex 350 in STL format 24. To create the prototype PolyJet photopolymers were used that simulate the appearance and functionality of polypropylene material Rigur (RGD450). Rigur (RGD450) is an advanced simulated polypropylene material that provides durability and gives a nice look to the final layer of the surface. 


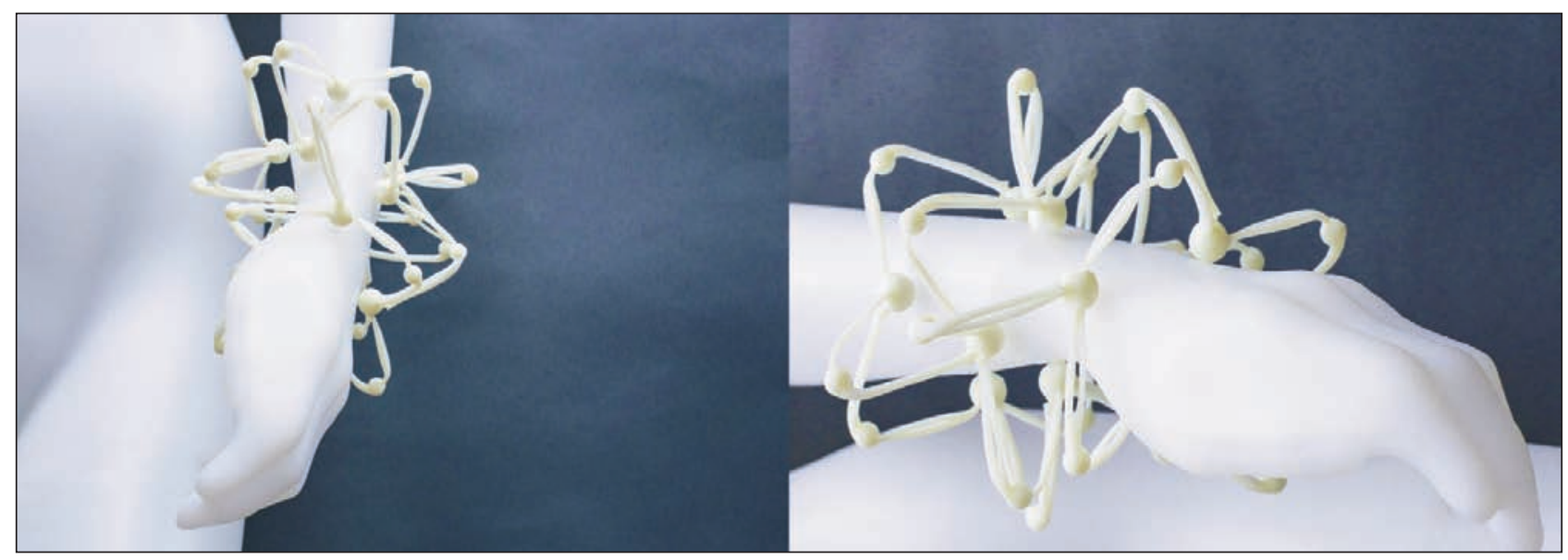

Fig. 6. The final Relief collection prototype bracelet

It is used for a quick printing of complex prototypes and demanding applications. It comes in white which ensures fine resolution and ultimately smooth curves of a printed product. It is flexible and resistant to shock, which is of crucial importance for ensuring the idea of mobility and flexibility in making corsets and accessories for the Relief collection (figure 6).

The design and manufacture of mechanical moving joints are fully achieved and successfully implemented in the clothing surface area and the surface area of fashion accessories. This resulted in maximum mobility and complete flexibility of the collection model to the human body. The Relief collection consists of three models: the corset, the necklace and the bracelet. On the model bracelet the fundamental design principle was achieved and can be used for other two models. The prototype was created in white, but the range of colour can be changed according to the consumer with each new printing since the additive technology enables personalization and unique production of products. Every consumer can choose the color, the size of the elements, their shape and their placement in the model and thus the consumer becomes a participant in creating individualized models.

\section{CONCLUSION}

In this research the understanding of art, of design and of modern technologies have been unified. The
Relief collection was created by studying the historical Victorian corset, mobile sculptures by Miroslav Šutej and additive technology. Through the collection's interdisciplinary approach to fashion design and clothing design, the moving, mechanical system/joint was created which in return was used to create a corset and fashion accessories such as necklaces and bracelets.

The tendency to emancipate the torso through changing the historically given idea of 'to corset' resulted in transformation of a rigid form into a mobile garment which does not inhibit the body.

An additional challenge to create a mobile garment is the fact that almost all approaches using 3D print additive techniques in contemporary fashion are static and sculptural or require further intervention. The intervention is often finishing work done by hand or connecting certain elements of 3D printing with textile materials which this collection aimed to avoid.

\section{ACKNOWLEDGEMENTS}

The authors would like to express their appreciation for Ass. Prof. Damir GUDEC (Faculty of Mechanical Engineering and Naval Architecture - University of Zagreb), Ass. Robert SURMA (Faculty of Mechanical Engineering and Naval Architecture, University of Zagreb) and Ivan ŠABAN (Studij dizajna - University of Zagreb) for their support.

\section{BIBLIOGRAPHY}

[1] Robinson, H.R. Oriental Armour (Dover Military History, Weapons, Armor), Dover Publications, Mineola, New York, 2001.

[2] Walker, F.P. The History of Armour 1100 - 1700, Crowood Press, Ramsbury, 2013.

[3] Koda, H. Extreme Beauty: The Body Transformed, Metropolitan Museum of Art, New York, 2001.

[4] Pilipović, A. News - Do not trust Wall Street when additive production is in question, In: Polimeri, 2016, vol. 36, issue 1, pp. 1-2.

[5] Clarke Bradock, S.E. Digital Visions for Fashion and Textiles: Made in Code, Thames and Hudson, London, 2012.

[6] http://www.hrleksikon.info/definicija/korzet.html

[7] Steele, V. The Corset, A Cultural History, Yale University Press, New Haven \& London, 2001. 
[8] Smrekar, A. Miroslav Šutej IMAGE/INATION - Drawings, Prints, Paintings and Objects 1962/1972, SKANER STUDIO, Zagreb, 2005.

[9] Mladen Šercer, M., Godec, D., Pilipović, A. Aditivne tehnologije za mala i srednje velika poduzeća, AD TEC EU, Zagreb, 2013.

\section{Authors: \\ JASMINKA KONČIĆ JOSIPA ŠČAPEC \\ University of Zagreb}

Faculty of Textile Technology, Department of Textile and Clothing Design

Prilaz baruna Filipovića 28a, 10000, Zagreb, Croatia

e-mail: HYPERLINK "mailto:jasminka.koncic@gmail.com" jasminka.koncic@gmail.com,

HYPERLINK "mailto:josipa.scapec@gmail.com" josipa.scapec@gmail.com

\section{Corresponding author:}

JASMINKA KONČIĆ

HYPERLINK "mailto:myukseloglu@marmara.edu.tr" jasminka.koncic@gmail.com

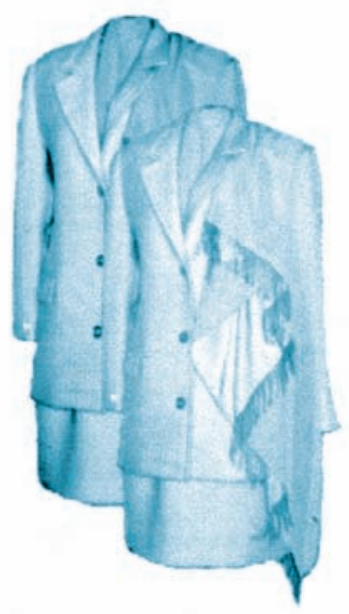

